\title{
Museums as Cultural Tourism Attractions in Ubud
}

\section{Ida Bagus Kade Subhiksu, I Wayan Ardika, Nyoman Darma Putra and I Nyoman Madiun}

\author{
School of Postgraduate Study \\ Doctorate Degree in Tourism Udayana University \\ Coressponding author: bagusiastp5@yahoo.com
}

\section{ARTICLE INFO}

Received

10 March 2014

Accepted

15 August 2014

Available online

10 September 2014

\section{ABSTRACT}

Recently, there has been a shift in the attributes of several museums in Ubud in order to attract more tourists to visit museums as cultural tourism attractions. Some museums have expanded their collections and add other attributes to complement their main collections, which as the potential to alter the idealism, functions, and roles of museums. Another challenge faced by museum operators is the development of other tourist attractions, such as the addition of tourism destination attributes in Ubud, which was initially known as tourism destinations that offered art and culture such as dance performances and museums, and now have expanded into yoga destination, adventure destination, and so on. Based on these factors, the problem statements in this research are formulated as follows: (1) How are museums as tourist attractions in Ubud area, from the perspective of operators? (2) How are museums as tourist attractions in Ubud area, from the perspective of visitors? (3) How is the relationship between museums and other tourism components when examined from the role of museums as cultural tourism attractions in Ubud area?. This research on museums was conducted in the Ubud area because Ubud has made museums as the cultural tourism attractions in the area, which include the Blanco Museum, Museum Puri Lukisan, Agung Rai Museum of Art (ARMA), the Rudana Museum, and Neka Art Museum. This research is based on the theories of museum management, marketing, and theories on cultural tourism attraction. The research involved the participation of 82 foreign visitors and 79 domestic visitors as respondents, in addition to five museum owners and two museum professionals as informants. The conclusion of this research are as follows: (1) From the perspective of museum operators, museums function as cultural tourism attractions, as sources of historical information, as the media for cultural preservation, and the actualization of the noble objective of the museum founders, which is to take the role as preservers of culture particularly in the form of paintings and sculptures. (2) Museums as cultural tourism attractions, according to visitors to the Ubud area, have been well managed and in accordance to the visitors' expectations. The perception of visitors on cultural tourism attractions in this research is observed from the elements of museum architecture, collections, layout, service quality, cleanliness, beauty, and hospitality, which indicates that all eight factors have been satisfactory, for both foreign and domestic tourists visiting the Ubud museums. (3) The museums have been able to sustain and improve the image of Ubud.

Keywords: museums, tourism attractions, cultural tourism, visitors, museum operators 


\section{Introduction}

\section{Background}

Recently, there has been a shift in the attributes of several museums in Ubud in order to attract more tourists to visit museums as cultural tourism attractions. Some museums have expanded their collections and add other attributes to complement their main collections, which as the potential to alter the idealism, functions, and roles of museums. As institutions of cultural preservation, community education, and quality recreational facilities for tourists, the sustainability of museums must be maintained.

From the viewpoint of museum operations as tourism destinations, operators are demanded to meet tourists' expectations as the main visitors of museums. On the other hand, operators fight to sustain their museums to keep their idealism as the institutions of cultural preservation, community education, and quality recreational facilities for tourists.

Another challenge faced by museum operators is the development of other tourist attractions, such as the addition of tourism destination attributes in Ubud, which was initially known as a tourism destination that offered art and culture such as dance performances and museums, and now has expanded into yoga destination, adventure destination, and so on. Reflecting from the current situation, a research on whether museums still exist as strong tourism attractions for Ubud is warranted. Based on this background information, several problem statements can be formulated as stated below.

\section{Research Objectives}

The general objective of this research is to analyze in general the existence of museums in Ubud in order to paint a clear picture for society on the role of museums as tourism attractions. The next objective is to clarify the position of museums as cultural tourism attractions. The main specific objective of this research is to clarify the position of museums as cultural tourism attraction in the Ubud area from the perspective of museum operators and visitors. Consequently, the next specific objective is to construct the relationships between museums with other tourism components when seen from museums' role as cultural tourism attractions in the Ubud area.

\section{Literature Review}

\section{Research on Museums in Bali}

Research related to museums as cultural tourism attractions in Bali is considered low in quantity. The research on museums conducted by the Bali Office for Tourism (Bali, 2011) on the analysis of the foreign tourist market segment visiting Bali museums recorded that the main problem in analyzing the market for museum tourism in Bali is the lack of comprehensive data. The data collected in this research was incomplete, segmented, and inaccurate. Several big museums seem professional in their management but the visitor data is not comprehensively available, which raised the question and doubt on the sustainability of museums as cultural tourism attractions. The available data was also not classified by the visitors' country of origin.

The findings in the research by the Bali Office for Tourism (Bali, 2011) recorded that tourist visits to museums in Bali from 2000 to 2009 show a general decline. This is quite alarming because it is not in line with the general trend of the increasing number of visitors to Bali in the same period, particularly after the Bali bombing tragedies of 2002 and 2005. In 2010, the number of tourists visiting Bali reached two million visitors. Logically, if the number of visitors to Bali shows an increasing trend, the number of visitors to museums in Bali should also show an increasing trend. The available statistics shows that the general trend of growth in the number of tourists visiting Bali is not felt or shown by the similar increase in the number of museum visitors. The number of visits to museums in Bali is relatively low. The available figures indicate that the average visit by tourists to a particular museum in Bali is lower than 10.000 visitors annually. When divided by 365 , that museum only receives an average of 30 visitors per day. This alarmingly low figure raises the question on the availability of sufficient revenue for operational and maintenance costs. 
The Bali Office for Tourism (Bali, 2011) also recorded that the number of visitors to a museum is determined by several internal and external factors. The internal factors relate to the quality of the museum's collections, the atmosphere and comfort of the exhibition chambers, service, general facilities for visitors, and museum popularity. External factor relates to the physical access to the location. Tourists who visit museums are undoubtedly drawn by the curiosity to appreciate the museum collections, to appreciate the masterpieces that possibly only exist in a particular museum. The better the quality, uniqueness, and authenticity of a museum's collections, the stronger the museum's appeal for visitors. The more popular or famous a museum, the stronger the museum's appeal as well. Some museums provide welcome drinks for visitors, already inclusive in the price of admissions. This type of service leaves a positive impression on the visitors and can be the basis for a deeper experience when viewing the museum's collections.

Another notable finding from the research by Bali Office for Tourism (Bali, 2011) relate to the prevalence of Japanese tourists as the most dominant visitors of museums in Bali. The available data indicates that tourist from Japan dominated as the number one visitors by country of origin in at least three main museums in Bali: The Bali Museum, The Neka Art Museum, and Museum Puri Lukisan. The high number of visitors is influence by both the internal factors (quality of collections, service, and facilities) and the external factors (location and parking area) that support the appeal of the museums.

\section{Research on Museums outside of Bali}

This section describes several research studies on museums outside of Bali, one of which is the research by Markovic, Raspor Jankovic and Komšić (2013) in Croatia investigating the quality of service in museums. This research aimed to measure the expectation of museum visitors and their perception on the service received. Conclusively, this research described the difference between visitors' expectation and the quality of museum service in Croatia.
The basis of the research by Markovic, Raspor Jankovic and Komšić (2013) is the study on consumer satisfaction, which belongs to the basic theory of consumer behavior. In this research, the analysis of consumer satisfaction was considered essential because of the increasingly tight competition between tourism destinations, the increasingly high visitor expectation, and the increasingly intense competition from tourism attractions other that museums. This research noted that the highest mark in visitor expectation was the expectation related to the freedom of access for the museum collections, which means that visitors had high expectations for the absence of restrictions to view and photograph the collections. Visitors also expected to obtain complete information on the museum exhibits. Seen from the perception of museum visitors, this research noted that the elderly visitors had the most difficulty in accessing museum collections.

However, the use of technology in museums was perceived highly positively by visitors as an important factor in attracting visitors. As a whole, this research found disparity between visitors' perception and expectation. Visitors' expectation was higher than the perception, thus it can be concluded that visitors were not completely satisfied with the services provided by museum operators in Croatia. The factor analysis in this research formed five essential factors that determine visitors in visiting a museum. These five factors are: (1) museum facilities, (2) accessibility, (3) appearance and exhibitions, (4) empathy of operators, and (5) communication and information for visitors.

\section{Concept}

\section{Tourism Destination and Tourism Attractions}

The conceptual definition of tourism destination, in the scope of this research, is the strategic area within one or more geographic or administrative areas of Ubud in which exists potentials for tourism attraction, high accessibility, the availability of public and tourism facilities, as well as socio-cultural activities in the communities that support tourism. The tourism attractions in this research refer to museums built and managed 
in the Ubud area to attract visitors. This conceptual definition is adopted from various sources, including the Law of the Republic of Indonesia no. 10 of 2009 regarding tourism, as well as definitions from various tourism experts.

\section{Museums as Tourism Attractions}

Museums are institutions established for the general public. Museums function to collect, preserve, display, and conserve cultural heritage of a society for the purpose of study, research, leisure, or entertainment. Based on Government Regulation of the Republic of Indonesia no. 19 of 1995, museum refers to an institution that serves as a place to store, preserve, secure, and utilize objects that are artifacts of human cultural development as well as the surrounding nature and environment, in order to support the efforts of protection and preservation of a nation's cultural richness. Meanwhile, according to the International Council of Museums Code of Ethics for Museums (ICOM), museum is a permanent not-for-profit entity that serves the public and societal development, open to the public, whose tasks include acquiring, preserving, connecting, and exhibiting artifacts that portray man's true identity and the surrounding nature for the purposes of research, education, and recreation.

\section{Theoretical Framework}

\section{Museum Management}

According to Leiper (2005) management refers to a set of roles performed by an individual or a group of individuals, or could refer to specific functions affixed to those roles. The functions of management include: planning, organizing, directing, and controlling. Pitana and Diarta (2009) stressed that coordination is the main and most important function of management that should be separated and discussed on its own.

The coordination function refers to the function of a manager to interpret certain information, such as information related to planning and controlling, and to apply such information in a systematic way into all managerial functions that can be translated into real actions in directing, planning, and

controlling the organization. The management of an organization is depicted in an organizational structure, in which each part has its own tasks, functions, and authorities that relate to and support one another as one integrated unit. Management theories in this research are used to understand the management of museums as cultural tourism attractions in Ubud.

\section{Museum Marketing}

According to Bradford (in Seymour and Moore, 2000), on the framework for museum marketing, there are several important categories in the study of museums and several important characteristics for successful curators. These categories point to three important orientations in successful museum activities: (1) museum management, (2) museum reputation, and (3) museum relationship with patrons. The term "patrons" is used for individual providing funds for a museum. This includes the local authorities, grant awarding body or a paying visitor. One of the characteristics of this categorization is the separation between those who determine museum reputation ("audience") and those who provide funding (local authorities, sponsors, funding agencies, and benefactors).

Building reputation for the visitors is crucial. This is not necessary in convincing sources of funding and in determining the financial success of a museum, particularly for museums that do not charge any admission fees. This is direct contrast with the consumer goods sector, in which reputation among customers and high sales values are the foundations of financial success. For museums, financial success at least in viability depends largely on the patrons. This means that museums understand the importance of keeping positive relationships with patrons. 


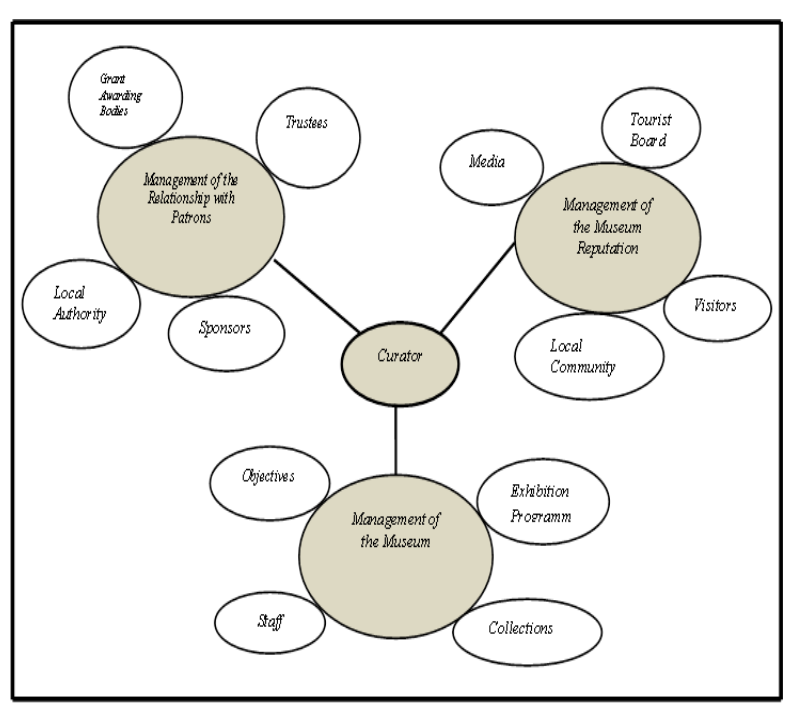

Figure 1. Diagram of Integrative Museum Management

Source: Bradford (in Moore, 2000:47)

The diagram in Figure 1 shows sound museum management including the operational flow for patrons, curators, and awarding bodies that show that the roles of each in museum managements such as: (a) in terms of relationship management with patrons, this closely relates to the local authorities, sponsors providing funds, grand awarding bodies and trustees, all of which are patrons of museums that should be well managed so that museums procure adequate funding for its operations, (b) in terms of reputation management related to the media, the tourism boards, local authorities, and visitors, the media hold an important role in promotion and image building supported by tourism institutions and the community so that the sustainability of tourist visits is ensured in the form of new and repeat visitors, (c) museum management depends on the collections, exhibitions, purpose, and staff. All these parts support one another in reaching the success of a museum. The curators, as shown in the diagram above, hold an essential role in relationship management, reputation management and museum management itself.

\section{Museum as Tourism Attractions}

Neil Leiper (2005) describe art museums as tourism attractions by applying theories related to: (1) structure and physical design, (2) causation, (3) process, (4) evolution, (5) hierarchy, and (6) originality, which can be described as follows:

1) Structure and Physical Design

It related to the structure and physical design of a cultural attraction, there are three important components to be considered: (1) nucleus, (2) inviolate belt and (3) zone of closure.

Firstly, the "nucleus" component related to the conceptualization of tourist attraction as the center of tourists' attention that becomes the basis of their creation or cultural experience. The nucleus of an art museum is the collection displayed as the reflection of reality, not only in terms of artworks being displayed but also in terms of museum as a place for recreation and cultural experience that can be focused on other phenomena. Museum as a tourist attraction is not only focused on the display pieces but also on the surroundings, which is termed "inviolate belt" forming one "zone of closure". For instance, in the Neka Art Museum, one nucleus element is when a visitor thinks about the place that he visits in terms of garden, building, art collection, and staff hospitality that becomes the base of that visitor's experience. Another nucleus is the entire art collection in that museum. Nucleus is made of small parts such as the arrangement of art displays based on Balinese traditional paintings in one chamber, paintings in the style of "Young Artist" in another, masterpieces of famed artist I Gusti Nyoman Lempad in yet another chamber, and masterpieces of Abdul Azis in a separate chamber. Museum as a tourist attraction draws visitors that make up the main element in the museum's attractiveness reciprocally: first, visitors observe other visitors and become interested in their behavior or appearance; second, the conversation that typically begins with foreign tourists who visit one museum in particular initially based on the attraction to one particularly famous masterpiece.

Secondly, the "inviolate belt" in a tourist attraction refers to things surrounding each nucleus, which has to be utilized effectively. Several kinds of inviolate belt and its dual function can be seen in museums; one of its functions is to guard the nucleus and the other one is to help visitors attain certain cultural experience, for example: high value paintings must be properly guarded in a museum and require several types of security measures to 
avoid damage and theft. Thirdly, the "zone of closure" in a tourist attraction refers to the components of attractiveness outside of the inviolate belt that function as the right place and right time for commercial activities and supporting facilities to be used by visitors. For instance, in the Neka Art Museum, the zone of closure includes spaces that connect one area to another such as the lobby to the information desk, areas that provide books and posters available for sale, the terrace of the café, public toilets, and parking area. None of these areas are essential for the visitors' experience, but they contribute to the visitor experience as a whole.

\section{2) Causation in Tourism Attractions}

Tourists are interested in visiting a place if there is a phenomenon that motivates them. This motivation requires that the information received be true or accurate that can react positively on individual needs and create motivation. The attractiveness of one place could create a certain influence on potential tourists, for example someone who wants to visit a museum at the very least has had some information about that particular museum prior to visiting. If a tourists is interested in visiting The Blanco Renaissance Museum, he would have learned about or gathered some information regarding the artist's erotic style of painting.

\section{3) Process in Tourism Attractions}

From the context of tourism, attractiveness does not happen in the literal sense, but rather is a process that cause tourists to point towards a nucleus or main tourist attraction. The process of attracting tourist involves three elements: a tourist, a sight, and a marker (referring to information about the sight received by a tourist). This relates to the information process, which is an important thing in tourism attractiveness. A sight becomes a marker that is an actionable information about a city or destination, for example a museum could act as a sight in a city or destination.

\section{4) Evolution in Tourism Attractions}

Evolution in the context of tourist attraction generally involves five phases: naming, framing, elevation (placement of an object in such a position that it is easy to recognize), shrinement (a process in which a site is known as a shrine or holy relic), and duplication (in the form of replication, photography, poster, post card, or model). These phases are accumulative, such that in the fifth phase the tourist attraction already has a name, a frame, elevation, shrine, and duplication.

5) Integrated Tourism Attractions and the Hierarchy

It may occur in a tourist's mind an experience centered on one particular attraction. It is also common for tourists to have multiple attractions in mind, prioritized from the primary, secondary, and tertiary attractions relevant for individual tourists or one stream of population. The primary attractions initially determine the decision to visit the place in which the nucleus exist in. This requires information received by potential tourists interacting with people who have certain stake to stimulate the potential tourists' motivation to make a decision visit a destination.

\section{6) Originality in Tourism Attractions}

The reputation of art museums relate to their originality, which is important in supporting the museums' reputation and success. In museums, tourists can attain knowledge, historical impressions, culture, and natural phenomena of the visited country or region. Museum is an efficient source to satisfy the need to learn about a place or region, particularly in terms of culture and other things necessary to have an authentic experience. Museum reputation is closely related to museum's role as an arbitrator of authentic city. Valuable art to be placed in a museum is considered due to its originality or from several aspects: the originality in terms of style, intellectual quality, and original works of famed artists. 


\section{Research Model}

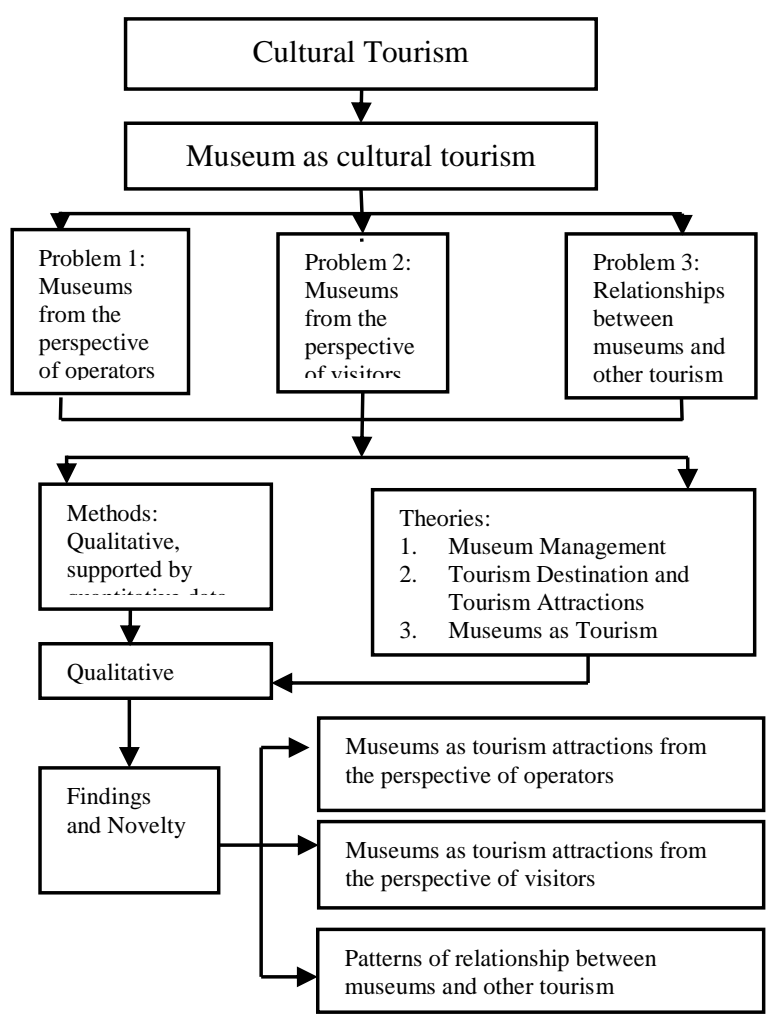

Figure 2. Research Model of Museums as Cultural Tourism Attractions

From the research questions, explored with various indicators and referring to theories and concepts as the basis of this research, the researcher expects to attain research output that can be used as the basis of recommendations to museum operators in managing museums sustainably as tourism attractions. Figure 2 graphically illustrates the model adopted for this research, which depicts that museum as tourism attractions do not have commercial objective as its main reason for existence, but rather have a noble objectives such as educational, recreational, and cultural preservation objectives. Ubud as a tourism destination has a particular uniqueness compared to other tourism destinations in Bali because of the existence of museums in the area as main tourism attractions. The existence of museums in Ubud attracts foreign and domestic visitors to the area, which possesses a certain uniqueness that warrants further research particularly on the roles of museums as tourism attractions. On the other hand, the roles of each museum in the development of tourism, as well as the relationships between museums with other tourism industry components, should be explored. The findings of this research is expected to answer three main points of concern: (1) museums as tourism attractions in the perspectives of operators, (2) museums as tourism attractions in the perspectives of visitors, and (3) the relationship patterns between museums and other tourism components in Ubud.

This research is expected to answer the main questions in order to attain findings that support museums as sustainable cultural tourism attractions, and is expected to create a pattern for the sustainable development of museums. This research is also expected to have theoretical and practical benefits for the continued existence of cultural tourism, particularly the culturally rich tourism in Bali.

\section{Methodology}

\section{Research Design}

This research is qualitative by design, utilizing data collection techniques through direct observation, in depth interview, distribution of questionnaire, and review of literature. The analysis is presented formally through tables and graphs and informally through narratives. Simple statistical analysis tools such as arithmetic means and frequency distribution are used to complement the qualitative analysis. This research also takes advantage of the established social phenomenon regarding the existence of museums in Ubud as cultural tourism attractions. The research findings are expected to construct a pattern of relationship between museums as cultural tourism attraction with other tourism components to realize sustainable cultural tourism particularly in the Ubud area.

\section{Research Location}

This research was conducted in the Ubud area, located in the Gianyar regency. Ubud is located $10 \mathrm{~km}$ north of the Gianyar city center and $25 \mathrm{~km}$ from Denpasar, the capital city of Bali. The consideration of Ubud museums as the location for research includes the popularity of the Ubud region as a cultural tourism destination, which already has several renowned museums for both domestic and foreign tourists. Another strong consideration 
is that Ubud has been known as the center of Balinese traditional painting since the 1930s (Leiper, 2004). Five museums are determined to be the research location: (1) Agung Rai Museum of Arts (ARMA), (2) The Blanco Museum, (3) The Neka Art Museum, (4) Museum Puri Lukisan, and (5) The Rudana Museum.

\section{Types and Sources of Data}

This research utilized two types of data: qualitative and quantitative. The qualitative data is the main type, and quantitative data is the supporting data. The sources of data in this research comprise of primary and secondary data, which can be explained as follows:

1) Primary data refers to the data obtained directly from the source, for example data from interviews with informants in this research.

2) Secondary data refers to data obtained through other sources that support the research but are not obtained directly from first-hand collection techniques. Secondary data includes books, literature reviews, scientific journals, and findings from previous research.

\section{Research Instruments}

The research instruments utilized for the data collection process in this research include: (1) researcher's direct participation, (2) questionnaire, (3) recorder for interviews, (4) digital camera to attain complete data from related stakeholders, so that the data obtained can fully answer the research questions. The interviews conducted in this research utilized the open-ended guided interview, which is a combination between open-ended and guided interview.

\section{Data Analysis}

The researcher descriptively describes the findings from each museum to be summarized in a brief consisting of empirical findings of museums as cultural tourism attractions in Ubud area. Descriptive qualitative analysis gave review and interpretation on the data and information collected, which is more meaningful than numerical representations only.

http://ojs.unud.ac.id/index.php/eot

\section{Data Collection Techniques}

Data collection technique is a strategic step in research, which should be in line with the research at hand to collect data. Data collection in this research was conducted through direct observation, distribution of questionnaires, interview, documentation, and data triangulation to obtain data validity. The specific techniques include: (1) directly observing five museums in the Ubud area; (2) distributing questionnaires in each museum to obtain data from visitors of each museum; (3) conducting in depth interviews with owners or operators of museums; and (4) conducting field study documentation.

\section{Results and Discussion}

\section{Characteristics of Museums as Research Objects}

Based on the qualitative description of data on the history each museum's founding, types of collections in each museum, form of organizational structure in each museum, marketing strategy applied, and the development of tourist visits to five museums in Ubud area, each of the five Ubud area museums has similarities and differences that complement one another.

These similarities and differences of museums as cultural tourism attractions in Ubud area can be elaborated as follows:

1) Based on the history of their founding: when observed from the history of each museum's founding, all museums in this research have similar characteristics as art museums, only the Rudana museum portrays itself with its dual roles as an art museum and art gallery, while the Blanco museum can be categorized as a single artist museum.

2) Based on the naming of the museums: when observed from the name sign on each museum's entrance, the museums have similarities in the use of both Indonesian and English. Museum Puri Lukisan adds to the English version of its name to become "Museum Puri Lukisan of Balinese Arts". Museum Neka (in Indonesian) also added another component to its English name equivalence to become "Neka Art 
Museum Ubud Bali”. Museum Rudana (in Indonesian) becomes "Museum Rudana \& Rudana Fine Art Gallery", $A R M A$ is an abbreviation of "Agung Rai Museum of Art", and Museum Blanco (in Indonesian) becomes "The Blanco Renaissance Museum". When seen from the naming strategy using dual languages, it is clear that the museum operators aim to showcase their museums to both domestic and foreign visitors.

3) Based on the types of collections: when observed from the types of collections in each museum, all five museums have collections in the form of paintings, but Museum Puri Lukisan adds to its painting collection with sculptures as additional attributes. Meanwhile, the Neka museum appears to be different than the other museums due to its keris (dagger) collection as an additional attribute for this museum. The Blanco museum also displays uniqueness by adding a bird park as an additional attribute in the museum's area.

4) Based on the application of promotional strategies: when observed from promotional strategies applied by the five museums in this research, all five museums utilize mixed promotional strategy particularly ARMA Museum that adds integrated strategy with other business units owned by its owners. Similarly, the Blanco Museum also applies mixed promotional strategy complemented by social media presence to increase visits to the museum. This research indicates that museum operators have applied its marketing functions in the management of museums as cultural tourism attractions in accordance to the assertion of Neil, et al (1998), which stated that museum marketing should be conducted to support the long-term sustainability of the museum. The five museums that become cultural tourism attractions in Ubud area have applied appropriate marketing functions including: (1) advertising, (2) positioning and branding, (3) public relations, and (4) direct marketing.

5) Based on the types of visitors: when observed from the dominant type of visitors to these five museums, it appears that all five museums are mostly popular

http://ojs.unud.ac.id/index.php/eot with foreign tourists. Rudana and Blanco museums are able to show their ability to attract a balanced proportion of domestic and foreign tourists.

6) Based on the application of management functions: when observed from the application of management functions in the management of museums as cultural tourism attractions in Ubud, it can be concluded that all five museums have applied appropriate management functions. Compared to the assertion of Wiludjeng (2007), the five museums in this research have been operated by managers or someone at the manager level in the application of museum management functions. These management functions include: (1) planning, as proven by the existence of vision and missions statements as well organizational objectives in all five museums, (2) organizing, as proven by the existence of job specifications in the form of organizational structure, resource allocation, organization, and coordination to implement the performance objectives of all five museums, (3) leadership, as proven by the presence of a director or manager in each museum to influence museum employees in contributing to the common objective and the goals of the museums, (4) controlling, as proven by the existence of "guest comment" questionnaires for visitors as an instrument for measuring and improvement of individual and organizational performance.

7) Based on the application of museum information systems: when seen from the application of museum information systems, based on the assertion of Szymansky, et al (1991), it can be concluded that all five museums as tourism attractions in Ubud have applied museum information system in the form of information on collections, information on research, information on exhibitions, and information on conservation. The information system on the management of museum resources is also present in each museum, covering information relating to: marketing, human resource, finance, equipment, legal and organizational, education and training, documentation and archive, and museum planning. 
Public information supporting the information on museum services are also available in all five museums in the form of information services on museum activities, library and archive within the museum, information on museum communities, and interactive service given by the employees in charge of information services in each of the five museums.

\section{Museums as Cultural Tourism Attractions from the Perspective of the Operators}

Museums as cultural tourism attractions from the perspective of the operator are seen to function not only as tourism attractions, but also as sources of historical information, as the media for cultural preservation, and the actualization of the noble objective of the museum founders, which is to take the role as preservers of culture particularly in the form of paintings and sculptures. Each museum's operators have adequately displayed certain uniqueness that attracts tourists to visit. Detailed conclusion regarding museums as cultural tourism attractions from the perspective of the operators can be elaborated as follows:

\section{1) Museum Founder's Idealism}

Each museum founder has his own noble idealism, even though there are noticeable difference among them but these differences depict a noble meaning, which is to sup-port the sustainability of tourism in Ubud. The observed differences in idealism among the museum fouders are as follows: (1) The idealism of The Rudana Museum funders is to actualize art. (2) The idealism behind the founding of the ARMA Museum is influenced by pragmatic values in answering real life challenges and with the goal of empowering the local community. (3) The idealism of the Blanco Museum is to actualize art masterpieces, particularly the paintings of Don Antonio Blanco. (4) The idealism behind the founding of Neka Art Museum is seen as the nearest to the perfectly ideal meaning of a museum, which is as a source of history, a source of information about the past, as a medium for preservation, and actualization of noble artworks, all of which are stated in the ideals and foundation of the Neka Art
Museum. (5) Museum Puri Lukisan has a simple idealism, which is art preservation based on the fear of obliteration of local artworks.

\section{2) Museum Uniqueness}

Each museum that becomes a tourist attraction should have its own uniqueness to draw visitors. The uniqueness of each Ubud museum in this study is described as follows: (1) the building of the Rudana Museum is attractive because it conceptually uses the metaphor of a human body consisting of the head, the torso, and the lower limbs. Each building and chamber has distinct collections, which have different meanings and values. (2) The ARMA Museum is distinct from the other museums in the sense that visitors not only can encounter artworks, but also herbs and plants with medicinal and economical value throughout the museum grounds. (3) The Blanco Museum has a distinct feature when compared to the other museums in Ubud. This distinction is also the museum's uniqueness. The Blanco Museum is designed to be typically European, which may not be unique in Europe but is very distinct in Bali in order to accommodate its European style collections. (4) The Art Neka Museum is unique because of its keris (dagger) collections. The museum consistently has collections from local Balinese artists and the arrays of paintings are consistently themed depicting nature, culture, and the contexts of Balinese lives. (5) Museum Puri Lukisan is built on a distinct economic motive, thus the uniqueness of this museum is based on its practicality especially in the smaller sizes of paintings to be easily carried by visitors interested in purchasing. These artworks are the products of local Ubud residents who still practice traditional paintings and sculptures. Since 2010, Museum Puri Lukisan added new attributes, namely Museum Marketing 3.0, a café, a gift shop, as well as other amenities and accommodation attributes to support the operational sustainability of Museum Puri Lukisan.

\section{3) Cultural Preservation Efforts}

The motive of art preservation has based the founding of each museums studied in this research, but each operator also has alterior motives in founding the museum. (1) The 
Rudana Museum was founded with the main goal of preservation particularly preserving arts and culture. (2) The ARMA museum was founded as a living culture, which means that the museum is not only visited dur-ing exhibitions but also can be visited anytime by the people in the community. (3) The role of museum as a source of knowledge and education is realized in the Blanco museum, seen by the high number of visits from students each year. (4) The Neka Art Museum was also founded to create an opportunity for society to learn, appreciate, and enjoy art, also as a long term investment for its owners to achieve solace and pride in the preservation of arts and culture. (5) Museum Puri Lukisan was founded as a space for self-actualization of cultural philosophers and artists to keep working. Museum Puri Lukisan explicitly stated its role as a preserver of arts and culture, particularly paintings and sculptures, in its vision and mission.

\section{4) The Role of Museums for Tourism}

The role of museums in Ubud area is to become the main tourism attractions to draw tourists to visit Ubud. The role of museums as tourism attractions is closely related to the development of accommodations in the Ubud area. The cooperation between museum operators and other related tourism and hospitality operators in Ubud has created a harmonious condition with the element of tourism amenities in the form of hotels and restaurants, which had developed by taking advantage of the role of museums as tourism attractions that had become the vision of tourism development in Gianyar regency and the Bali province. The five museums have performed their roles as cultural preservers and education providers for the general public including domestic and foreign tourists. In addition to their roles in cultural preservation, particularly the Balinese culture, the five museums, i.e., Museum Puri Lukisan, Neka Art Museum, ARMA, Rudana Museum, and Blanco Museum have become cultural tourism attractions for the Ubud area. The role of Ubud area museums as institutions of cultural preservation is highly supported by the local authorities. Various forms of support had been provided for museum operators in Ubud, in terms of awards, provision of legal permits, protection, and other programs that relate to preservation of arts and culture. Museums as tourism attractions have also been able to provide employment opportunities for the local community, directly and indirectly. The existence of museums has become a popular tourism draw for the Ubud area, such that related business providing accommodation and travel services have grown tremendously and have also been able to absorb the local labor force.

It can be explained that the role of museums is to become the cultural tourism attractions especially for the Ubud area. Another role is museum as institutions of cultural preservation and education, especially for the young generation, particularly for Balinese arts and culture.

\section{Museums as Cultural Tourism Attractions from the Perspective of the Visitors}

The findings from the current research indicate that museums as cultural tourism attractions in the Ubud area have met the visitors' expectations, seen from the five dimensions of service quality. In general, it can be concluded that museums as cultural tourism attractions have met the expectations of most visitors to the Ubud area (see Table 1).

Table 1. Perception of Visitors on Museums

\begin{tabular}{|c|c|c|c|}
\hline $\begin{array}{l}\text { Operational } \\
\text { Elements }\end{array}$ & $\begin{array}{l}\text { Foreign } \\
\text { Visitors }\end{array}$ & $\begin{array}{l}\text { Domestic } \\
\text { Visitors }\end{array}$ & $\begin{array}{l}\text { Recommen } \\
\text { dations for } \\
\text { Operators }\end{array}$ \\
\hline 1. Architecture & Very Good & Very Good & Maintain \\
\hline 2. Collection & Very Good & Very Good & Maintain \\
\hline 3. Layout & Very Good & Very Good & Maintain \\
\hline $\begin{array}{l}\text { 4. Supporting } \\
\text { Facilities }\end{array}$ & Good & Good & Improve \\
\hline 5. Information & Accurate & Clear & Improve \\
\hline 6. Service Quality & Very Good & Very Good & Maintain \\
\hline 7. Cleanliness & Very Clean & Very Clean & Maintain \\
\hline 8. Beauty & Very Beautiful & Very Beautiful & Maintain \\
\hline 9. Security & Secure & Secure & Improve \\
\hline 10. Hospitality & Very Hospitable & Very Hospitable & Maintain \\
\hline
\end{tabular}

Source: Research findings, 2014

In detail, the perception of visitors on museums as cultural tourism attractions in Ubud can be illustrated as follows:

[1] Architecture: The perception of foreign and domestic visitors on the architectural element of Ubud museums is very good, thus this element should be maintained in the management of museums as tourism 
attractions, for example architecture that reflects the Balinese philosophy.

[2] Collection: The perception of foreign and domestic visitors on the collection element of Ubud museums is very good, thus this element should also be maintained in the management of museums as tourism attractions, for instance the classical, traditional, young artist, and modern styles of painting.

[3] Layout: The perception of foreign and domestic visitors on museum layout is very good, thus this element should also be maintained in the management of museums as tourism attractions, for example layout that reflects the cultural values relating to spatial arrangements, aesthetic values harmonious and coherent with the Balinese philosophy.

[4] Auxiliary Facilities: The perception of foreign and domestic visitors on museum auxiliary facilities is generally good but should be improved in the management of museums as tourism attractions, for instance parking areas, air conditioning, rest areas, and restaurants.

[5] Information: The perception of foreign and domestic visitors on museum information is accurate, thus this element should be improved in the management of museums as tourism attraction, for example by providing information on museum history, types of collections, books, and other supporting documents.

[6] Service Quality: The perception of foreign and domestic visitors on service quality is very good, thus this element should also be maintained in the management of museums as tourism attractions, for example providing quick and friendly service, providing guides in viewing the collection and providing other information throughout the museum.

[7] Cleanliness: The perception of foreign and domestic visitors on museum cleanliness is very clean, thus this element should also be maintained in the management of museums as tourism attractions, for instance by improving the general cleanliness and maintenance of the museum and the collections.

[8] Beauty: The perception of foreign and domestic visitors on museum beauty is very beautiful, thus this element should

http://ojs.unud.ac.id/index.php/eot also be maintained in the management of museums as tourism attractions, for instance by maintaining the beauty and aesthetics of the enclosed gardens and maintaining spatial aesthetics with Balinese philosophical concepts.

[9] Security: The perception of foreign and domestic visitors on museum security is secure, but this element should be improved in the management of museums as tourism attraction, for example by providing safety and security markers for collections that should not be touched, should not be photographed, and so on.

[10] Hospitality: The perception of foreign and domestic visitors on museum hospitality is very friendly, thus this element should also be maintained in the management of museums as tourism attractions, for instance maintaining the habits of smiling, thanking the guests, and so on.

\section{The Relationship between Museums as cultural Tourism Attractions with other Tourism Components inUbud Area}

The relationship between museums as cultural tourism attractions with other tourism components in Ubud in this research is the synthesis of qualitative data collected from interviews with several informants from tourism operators and tourism practitioners with extensive knowledge and experience in developing and marketing museums as tourism attractions especially in Ubud area.

According to Neka (1989) museums should be managed just as a business in order to survive and thrive sustainably. Sound human resource management, financial management, and marketing management are essential. Depicted simply, the roles and relationships between museums and other tourism components as cultural tourism attractions in Ubud is illustrated by Figure 3 below: 


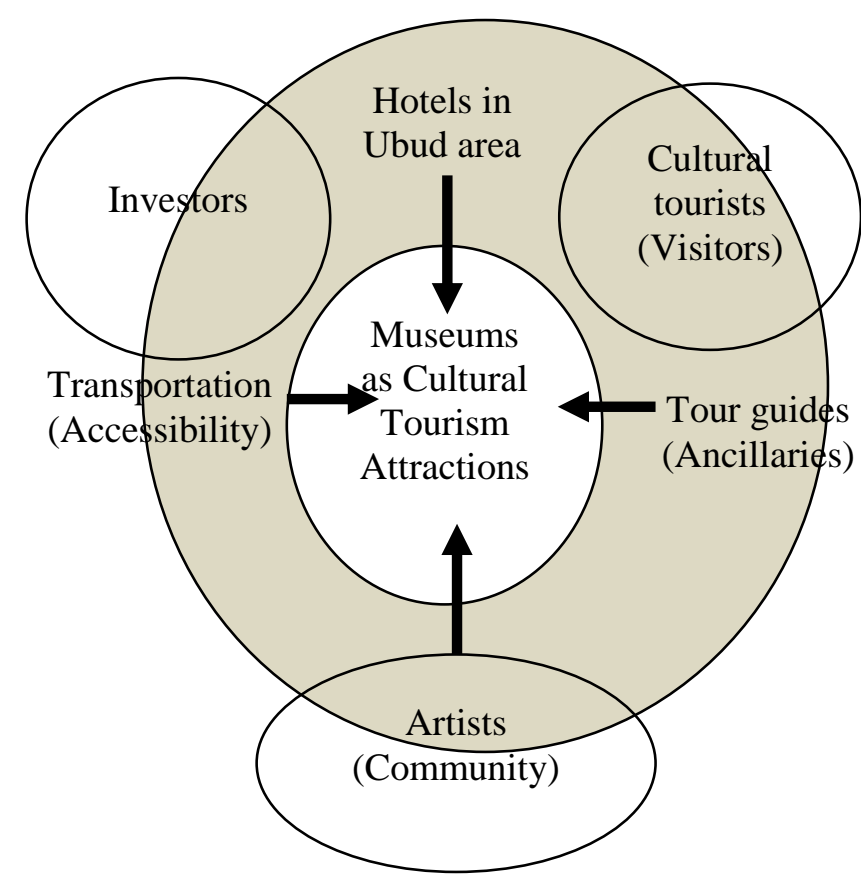

Figure 3. Ideal Model of Museums as Tourism Attractions Modified from Postma (2002)

Figure 3 depicts the circle as museum in its role as an attraction offered to tourists, meanwhile the amenities, ancillaries, and accessibility are supporting factors and form the totality of a tourism product in which museum is the center. All the factors forming the totality of this tourism product involve the local community in all levels. There are three stakeholders interested in the sustained quality of this totality of tourism product: the local community that agrees to build the museum as a tourist attraction to improve the community's quality of life, the visitors who deserve quality tourist attraction in accordance to their expectations, and the investors (government or private) interested in quality profits.

Simply put, the relationship between museums as tourist attractions with other tourism components such as amenities, accessibility, community, and ancillaries have been maintained harmoniously to actualize the quality visitors' experience, quality of life for the local community, and quality investment in the Ubud area. The utilization of museums as cultural tourism attractions in Ubud has already met the visitors' expectations. Museums as cultural tourism attractions, from the perspective of visitors, have met the expectations of most tourists visiting Ubud. The existence of museums as tourist attractions have been able to draw visitors to come to Ubud. The designation of Ubud as art and cultural village is appropriate and supported by the existence of museums that have played their roles as institutions of art and cultural preservation, especially for paintings and sculptures, as the media for educating society on art history and cultural history, and as a place for recreation for tourists.

The good relationship between the authorities and Ubud area museums should be increased in order to be an effective regulator and evaluator, to avoid unhealthy competition among museum operators. Aside from their roles as institutions of cultural preservation and as the main tourist attractions in Ubud, museums also play another role in terms of community empowerment especially in providing employment for local labor and providing a space to store and display works of local artists.

\section{Conclusion and Recommendation}

\section{Conclusion}

1) Museums as Cultural Tourism Attractions Museum from the Perspective of Operators

From the perspective of operators, museums function as tourist attractions and become the sources of historical information, as the media for cultural preservation, and the actualization of the noble objective of the museum founders, which is to take the role as preservers of culture particularly in the form of paintings and sculptures. Each museum operator have exhibited each museum's own uniqueness to attract visitors to visit.

2) Museums as Cultural Tourism Attractions Museum from the Perspective of Visitors

Museums as cultural tourism attractions, from the perspective of visitors to the Ubud area, are considered well-managed and in accordance to the visitors' expectations. The perception of visitors on museums as cultural tourism attractions in this research is seen from the elements of architecture, collection, 
layout, service quality, cleanliness, beauty, and hospitality, which indicated that these elements have been sufficiently met the visitors' expectations, for both foreign and domestic tourists. Several elements should be improved in quality, including auxiliary facilities, information on each museum and its collection, and museum security.

3) The Relationship between Museums as Cultural Tourism Attractions with Other Tourism Components in Ubud Area

The relationships between the museums as cultural tourism attractions with other tourism components in Ubud are associated collaborate. Museums as cultural tourism attractions are closely related to the development of accommodations in Ubud area, as proven by several museum operators offering packages in cooperation with area hotels to introduce or promote their museums as tourism attractions.

\section{Recommendations}

The findings from the current research suggest that related stakeholders, including tour guides, tour operators, and the government agencies, should encourage the development museums as tourism attractions because museums have other noble purposes as institutions of cultural preservation, as institutions of learning for the young generation, and as institutions that empower local communities by providing employment.

Museum operators should station their most knowledgeable staff members regarding the museum's exhibits and history at an information center within the museum. Providing other auxiliary facilities such as waiting rooms, sitting rooms, multimedia room, and internet connection, would increase the comfort level of visitors. In order to keep the changes in the roles and functions of museums within the corridor of tasks and functions of museums, museum operators should remain consistent to the idealism of museums' initial founders, which is keeping the roles of museums as institutions of preservation, conservation, education, and other roles as prescribed be museum institutions and regulators on the national and international levels.
Museum operators should always attempt to balance the needs for preservation and education because the two are complementary. Museum operators should consider the recommendations from this research, by improving the cooperation system with operators of tours and travel as well as tour guides as the supplier of visitors to make museums as a part of tourism packages offered to tourists interested in visiting Ubud.

\section{References}

Bali, D. P. P. (2011) 'Analisa Pasar Wisatawan Mancanegara Pengunjung Museum'. Denpasar.

Leiper, N. (2004) Tourism management. Pearson Education Australia Frenchs Forest.

Leiper, N. (2005) The Neka art museum: A study of a successful tourist attraction in Bali. School of Tourism and Hospitality Management Southern Cross.

Markovic, S., Raspor Jankovic, S. and Komšić, J. (2013) 'Museum service quality measurement using the Histoqual Model'.

Neil Leiper (2005) Museum Seni Neka Kajian Mengenai Keberhasilan Atraksi Wisata di Bali. Ubud: Neka Foundation.

Neka, S. (1989) The Development of Painting in Bali. Ubud: Yayasan Dharma Seni Museum Neka.

Pitana, I. G. and Diarta, I. K. S. (2009) 'Pengantar ilmu pariwisata', Yogyakarta: Andi.

Postma, A. (2002) 'An Approach for integrated development of quality tourism', Flanagan, S., Ruddy, J., Andrews, (2002).

Seymour, M. and Moore, S. (2000) Effective crisis management: Worldwide principles and practice. Cassell.

Wiludjeng, S. (2007) 'Pengantar Manajemen', Yogyakarta: Graha Ilmu.

e-ISSN: 2407-392X. p-ISSN: 2541-0857 